American Journal of Applied Sciences 6 (8): 1473-1477, 2009

ISSN 1546-9239

(C) 2009 Science Publications

\title{
The Impact of Macroeconomic Indicators on Agricultural Trade Balance of Iran
}

\author{
S. Yazdani and S. Shajari \\ Department of Agricultural Economics, University of Tehran, Iran
}

\begin{abstract}
Problem statement: One of the main targets of Iran's economic development plans in agricultural sector during the recent years was to augment agricultural exports and establish a positive trade balance in this sector. In this research the impact of macroeconomic indicators of Iran and its 20 trading partners on Iran's agricultural trade balance had been investigated. Approach: The ARDL approach was applied during the period of (1960-2005). Results: The domestic real income had the highest effect on the agricultural trade balance relative to other indicators both in the short-and longrun period. On the other hand, domestic money supply and foreign real income had the lowest effect in long-run and short-run respectively. In addition, real exchange rate had the positive impact on trade balance indicating that the depreciation will improve trade balance. But this is not a robust political instrument for establishing long-run equilibrium. Finally, the ECM results implied the fairly high speed of adjustment to equilibrium. Conclusion: The policies that tend to increase domestic income should be planned in such a way that the increased purchasing power of people will be directed to domestic goods rather than foreign goods.
\end{abstract}

Key words: Agricultural trade, Iran, macroeconomic indicators, equilibrium

\section{INTRODUCTION}

During the first 5 year development plan (19871991) the expansion policies, resulted in rapid economic growth and high trade deficit. It was expected that improved relative prices would diminished trade deficit in the long-run, but the occurrence of debt crisis in 1994 and high shrinkage of imports due to quantitative limits, revealed that the policy makers, lacked power to improve the trade balance flow ${ }^{[1,2,8]}$.

In the period after Islamic revolution, the agricultural trade balance was always negative. But, for the first time, it became positive in 2003, due to shift in agricultural production, enhanced value added and also better planning. Moreover, the volume of non-oil exports reached to $\$ 16.3$ billion in 2006 that showed approximately $47.2 \%$ growth in comparison with the previous year. Agricultural sector with $4.5 \%$ of volume and $13.1 \%$ of value, assigned the third position after petrochemical and industry sectors (customs administration of Islamic republic of Iran, 2006). However, it's still a long way for agricultural sector to reach its real place in international markets. Therefore, the identification of macroeconomic relationship between income, exchange rate, money supply and trade balance, is an important issue. Among them
Exchange rate is a significant factor in determining trade balance. Investigating the impact of devaluation on trade balance has been studied extensively during the past 20 years.

The impact of devaluation on trade balance is based upon the Marshall Learner's condition; which states that if the sum of the demand elasticities of exports and imports are greater than unity, then the devaluation would improve trade balance in the long-run.

The J-curve hypothesis predicts that the trade balance, as a result of devaluation, will first worsen and then after the passage of sometime it will start to improve. This pattern is mainly caused by the lagged response to the devaluation of the real flows ${ }^{[13]}$.

There has been a great number of researches empirically investigated the impact of exchange rate changes on trade balance. The majority group of these studies have been done on the aggregate level not within the sectors ${ }^{[3,4,12]}$. Rose and Yellen ${ }^{[11]}$ investigated the impact of exchange rate changes on trade balance between US and her six major trading partners for the period 1960-1985 and do not find evidence of the Jcurve effect.

On the other hand, some of the researches investigated the impact of exchange rate changes on trade balance in agricultural sector. Most of these

Corresponding Author: S. Yazdani, Department of Agricultural Economics, University of Tehran, University of Tehran, Iran Tel/Fax: +98-261-2247783 
studies have been done in $\mathrm{US}^{[2,6]}$. Their Results suggested that the exchange rate is the key determinant of the short-and long-run behavior of the trade balance. It is also found that the income and money supply in both the United States and the trading partners have significant impacts on the US agricultural trade in both the short-and long-run.

The time-series data between Iran and its 20 trading partners during the period of (1960-2005) have been used in this research. These 20 trading partners almost account for $60 \%$ of Iran agricultural trade balance.

\section{MATERIALS AND METHODS}

The empirical trade balance model used in this study following the literature is specified as follows:

$$
\begin{aligned}
\mathrm{LTB}_{\mathrm{t}}= & \alpha_{0}+\alpha_{1} \mathrm{LY}_{\mathrm{t}}+\alpha_{2} \mathrm{LYF}_{\mathrm{t}}+\alpha_{3} \mathrm{LM}_{\mathrm{t}}+\alpha_{4} \mathrm{LMF}_{\mathrm{t}} \\
& +\alpha_{5} \mathrm{LRE}_{\mathrm{t}}+\alpha_{6} \mathrm{DW}_{\mathrm{t}}+\mathrm{u}_{\mathrm{t}}
\end{aligned}
$$

Where:

$\mathrm{TB}=$ The measure of trade balance defined as the excess of real exports over real imports

$\mathrm{Y}=$ The real domestic income

$\mathrm{YF}=$ The weighted average of the foreign income

$\mathrm{M}=$ The real domestic high-powered money

MF = The weighted average of the foreign highpowered money

$\mathrm{RE}=$ Weighted average of real exchange rate index between Iran's Rials and 20 trading partners' currency

$\mathrm{DW}=\mathrm{A}$ dummy variable to represents the effect of Iran- Iraq war

$\mathrm{L}=$ Stands for the natural logarithm

$\mathrm{U}=$ The error term

Respecting the signs of the coefficients in Eq. 1, it is expected that an estimate of $\alpha_{1}$ would be negative, because an increase in domestic income, will lead to an increase in imports and as a consequence trade balance will be diminished. However, if domestic production of importable goods grows faster than consumption, then $\alpha_{1}$ could be positive ${ }^{[7]}$. Estimated value of $\alpha_{2}$, would be positive, since a rise in foreign income, leads to a rise in exports thereby improving trade balance. Domestic money is expected to have a negative sign, as by increasing the money, it will be assumed as an increase in wealth, therefore the expenditure will be raised and the trade balance will be worsened. By similar reasoning it's expected that $\alpha_{4}>0$. Finally the exchange rate is expected to have a positive sign if real depreciation is to increase exports and lower imports, which also satisfies the ML condition. But in the short-run, based on the $\mathrm{j}$-curve hypothesis, it's expected that $\alpha_{5}<0$.
To Investigate the short-run relationship, an Autoregressive Distributed Lag (ARDL) model developed by Pesaran and $\operatorname{shin}^{[9,10]}$ has been employed in this study $(10,11)$. An Error-Correction Model (ECM) derived from the ARDL model can be used to estimate the short- and long- run parameters of the model simultaneously ${ }^{[3]}$.

The ARDL model of Eq. 1 can be formulated as follows:

$$
\begin{aligned}
\Delta \mathrm{LTB}_{\mathrm{t}}= & \alpha_{0}+\sum_{\mathrm{i}=1}^{\mathrm{m}} \beta_{\mathrm{i}} \Delta \mathrm{LTB}_{\mathrm{t}-\mathrm{i}}+\sum_{\mathrm{i}=1}^{\mathrm{m}} \gamma_{\mathrm{i}} \Delta \mathrm{LYF}_{\mathrm{t}-1} \\
& +\sum_{\mathrm{i}=1}^{\mathrm{p}} \varepsilon_{\mathrm{i}} \Delta \mathrm{LM}_{\mathrm{t}-1} \sum_{\mathrm{i}=1}^{\mathrm{q}} \zeta_{\mathrm{i}} \Delta \mathrm{LMF}_{\mathrm{t}-1} \\
& +\sum_{\mathrm{i}=1}^{\mathrm{r}} \eta_{\mathrm{i}} \Delta \mathrm{LER}_{\mathrm{t}-\mathrm{i}}+\gamma \mathrm{LY}_{\mathrm{t}}+\delta \mathrm{LYF}_{\mathrm{t}+} \varepsilon \operatorname{ln\mathrm {H}_{\mathrm {t}}} \\
& +\zeta \mathrm{LMF}_{\mathrm{t}}+\eta \mathrm{LER}_{\mathrm{t}+} \varphi \mathrm{DR}_{\mathrm{t}}+\mathrm{v}_{\mathrm{t}}
\end{aligned}
$$

where, $\mathrm{m}, \mathrm{n}, \mathrm{o}, \mathrm{p}, \mathrm{p}$ and $\mathrm{r}$ are Optimum lags for LTBt, LYt, LYFt, LMt, LMFt and LERt variables respectively.

This approach involves two steps for estimating long run relationship ${ }^{[10]}$. The first step is to investigate the existence of long run relationship among all variables in the equation under estimation. If the sum of the estimated coefficients of the lagged dependent variable is less than 1, then the dynamic model will tend to long-run equilibrium. Therefore, for testing the existence of the long-run relationship among the variables, the hypothesis testing should be carrying out as follows:

$\mathrm{H}_{0}: \sum_{\mathrm{i}=1}^{\mathrm{m}} \beta_{\mathrm{i}}-1 \geq 0$

$\mathrm{H}_{1}: \sum_{\mathrm{i}=1}^{\mathrm{m}} \beta_{\mathrm{i}}-1<0$

Then the t-statistics for this test is calculated as:

$t=\frac{\sum_{i=1}^{m} \beta i-1}{\sum_{i=1}^{m} \operatorname{Se}(\beta i)}$

If the calculated t-statistics is greater than critical t, developed, then there is a long-run relationship among the variables of the model ${ }^{[5]}$. The second step is to estimate the long run and short run coefficients of the same equation. We run second step only if we find a long run relationship in the first step ${ }^{[8]}$.

The Error Correction Model (ECM) linked to the ARDL model can be stated as follows: 


$$
\begin{aligned}
\Delta \mathrm{LTB}_{\mathrm{t}}= & \alpha_{0}+\sum_{\mathrm{i}=1}^{\mathrm{m}} \beta_{\mathrm{i}} \Delta \mathrm{LTB}_{\mathrm{t}-\mathrm{i}}+\sum_{\mathrm{i}=1}^{\mathrm{n}} \gamma_{\mathrm{i}} \Delta \mathrm{LY}_{\mathrm{t}-\mathrm{i}}+\sum_{\mathrm{i}=1}^{\mathrm{o}} \delta_{\mathrm{i}} \Delta \mathrm{LYF}_{\mathrm{t}-\mathrm{i}} \\
& +\sum_{\mathrm{i}=1}^{\mathrm{q}} \varepsilon_{\mathrm{i}} \Delta \mathrm{LM}_{\mathrm{t}-\mathrm{i}}+\sum_{\mathrm{i}=1}^{\mathrm{r}} \zeta_{\mathrm{i}} \Delta \mathrm{LMF}_{\mathrm{t}-\mathrm{i}}+\sum_{\mathrm{i}=1}^{\mathrm{s}} \eta_{\mathrm{i}} \Delta \mathrm{LER}_{\mathrm{t}-\mathrm{i}} \\
& +\varphi \mathrm{DR}_{\mathrm{t}}+\lambda \mathrm{EC}_{\mathrm{t}-1+} \mathrm{u}_{\mathrm{t}}
\end{aligned}
$$

Where:

$\lambda=$ The speed of adjustment parameter

$\mathrm{EC}=$ The residuals estimated from equation

It is expected that the sign of $\lambda$ would be negative and its value would be changing between -1 and zero.

The annual data covering the period from 19602005 have been used. Agricultural trade balance is defined as the ratio of exports to imports. To calculate foreign income and money supply, it's required to compute trade weights of Iran's 20 trading partners. These weights are calculated by dividing the sum of the exports and imports value of each partner on total value of exports and imports of 20 partners.

\section{RESULTS}

The results of Augmented Dickey-Fuller Test (ADF) for the time series variables shown in Table 1 indicate that all of the variables contain a unit root in their levels but are stationary in their first differences; hence they are integrated of the first order.

After determining integrating order of all variables, the long-run trade balance model in Eq. 2 has been estimated. Since all observations are annual and the number of observations is limited, then the maximum order of lag in the ARDL model has been chosen as 2, employing Schwarz Bayesian Criterion (SBC). The results of the co-integration test of the dynamic model of ARDL are shown in Table 2.

According to the results, there is a long-run cointegration relationship among the variables of the model. Having found a long-run relationship, the ARDL model has been applied to estimate the long run and the short run elasticities (10). The estimated coefficients of the long-run ARDL model, has been reported in Table 3.

The results show that all estimates- except foreign money supply-are significant and have the expected signs (Table 3 ). The coefficient of the domestic real income is equal to -0.7613 and has the negative relationship with agricultural trade balance. Also it has the greatest impact on the agricultural trade balance among other variables. Negative coefficient of the domestic real income implies that an increase in real domestic income leads to a rise in Iran agricultural imports through the increased purchasing power of Iranian consumers, thereby decreasing the trade surplus.
Table 1: ADF unit root test on variables

\begin{tabular}{|c|c|c|c|}
\hline Variables & Coefficient & Standard error & t-ratio \\
\hline $\mathrm{C}$ & 14.9653 & 3.71230 & $4.0313 * * *$ \\
\hline LTB (-1) & -0.0833 & 0.10300 & -0.8087 \\
\hline LTB $(-2)$ & 0.2721 & 0.07490 & $-3.6328 * * *$ \\
\hline LY & -0.2849 & 0.09068 & $-3.1420 * * *$ \\
\hline LY (-1) & -0.3173 & 0.08000 & $-3.9662 * * *$ \\
\hline LYF & 0.0612 & 0.03770 & 1.6233 \\
\hline $\operatorname{LYF}(-1)$ & 0.1315 & 0.04020 & $3.2712 * * *$ \\
\hline LER & 0.0739 & 0.02210 & $3.3464 * * *$ \\
\hline LER (-1) & 0.8560 & 0.37330 & $2.2931 * *$ \\
\hline LM & -1.5430 & 0.46910 & $3.2894 * * *$ \\
\hline LMF & 0.0250 & 0.12320 & 0.2036 \\
\hline DR & -0.0889 & -0.37020 & 0.2402 \\
\hline $\mathrm{DR}(-1)$ & -0.0435 & -0.01354 & $3.4712 * * *$ \\
\hline
\end{tabular}

\begin{tabular}{lcc}
\hline Variables & ADF test statistics & 1st difference ADF statistics \\
\hline LTB & -2.51 & $-5.96^{* * *}$ \\
LY & -2.10 & $-6.42^{* * *}$ \\
LYF & -1.80 & $-4.10^{* * *}$ \\
LM & -2.41 & $-4.46^{* * *}$ \\
LMF & -1.37 & $-3.57^{* *}$ \\
LER & -2.25 & $-4.33^{* * *}$ \\
\hline$* * * *$ and $* * *$. Significant at 10,5 and $1 \%$ level of significance
\end{tabular}

Table 2: Estimated coefficient s of ARDL

$\mathrm{F}=30.2378(0.00), \mathrm{R}^{2}=0.9246, \mathrm{DW}=2.19$

\begin{tabular}{|c|c|c|c|}
\hline Variables & Coefficient & Standard error & t-ratio \\
\hline $\mathrm{C}$ & 18.8321 & 5.0723 & 3.7127 *** \\
\hline LY & -0.7613 & 0.1321 & $-5.7630 * * *$ \\
\hline LYF & 0.2425 & 0.0601 & $4.0349 * * *$ \\
\hline LER & 0.3518 & 0.1099 & $3.2010 * * *$ \\
\hline LM & -0.1707 & 0.0479 & $-3.5636 * * *$ \\
\hline LMF & -0.0062 & -0.0283 & -0.2190 \\
\hline DW & -0.2034 & 0.0817 & $-2.4870 * *$ \\
\hline
\end{tabular}

Table 3: Estimated long-run coefficients for ARDL (2,1,1,1,0,0,2) model

Agricultural trade balance has a positive relationship with foreign real income regarding the estimated coefficient of 0.2425 . According to the positive sign of this coefficient, with one percent increase in real income of trading partners, the trade balance, will rise about $0.2425 \%$, because by enhancing their purchasing power, they will demand more goods and hence the trade balance will increase.

On the other hand, the positive coefficient of real exchange rate indicates that in the long-run, a rise in the index causes an increase in exports and a decrease in imports, hence increasing the trade surplus. But, regarding its value, this is not a robust political instrument for establishing long-run equilibrium. The negative estimated coefficient of domestic money supply $(-0.1707)$ reveals that a rise in Iran money supply tends to deteriorate the trade surplus since an increase in domestic money supply will be assumed as a rise in net wealth, thus spending, which includes imports, will increase, leading to a worsening in trade balance. 
Table 4: Estimated short-run coefficients for ARDL $(2,1,1,1,0,0,2)$ model

\begin{tabular}{lclc}
\hline Variables & Coefficient & Standard error & t-ratio \\
\hline$\Delta$ LTB & -0.2734 & 0.0756 & $-3.6125^{* * *}$ \\
$\Delta \mathrm{LY}$ & -0.2816 & 0.0896 & $-3.1402^{* * *}$ \\
$\Delta \mathrm{LYF}$ & 0.0679 & 0.0257 & $2.6387^{* * *}$ \\
$\Delta \mathrm{LRE}$ & 0.1322 & 0.0580 & $2.2764^{* *}$ \\
$\Delta \mathrm{LM}$ & -0.1403 & 0.0427 & $-3.2847^{* * *}$ \\
$\Delta \mathrm{LMF}$ & 0.0046 & 0.0225 & 0.2036 \\
$\Delta \mathrm{DW}$ & -0.0891 & 0.3700 & -0.2408 \\
$\Delta \mathrm{DW}(-1)$ & -0.2620 & 0.0753 & $-3.4781^{* * *}$ \\
$\Delta \mathrm{C}$ & 14.9372 & 3.7041 & $4.0326^{* * *}$ \\
Ecm (-1) & -0.6013 & 0.0640 & $-9.3891^{* * *}$ \\
\hline $\mathrm{F}=26.2749(0.00), \mathrm{R}^{2}=0.88231, \mathrm{DW}=2.18$, Note: $*, * *$ and $* * *$ \\
Significant at 10,5 and $1 \%$ level respectively
\end{tabular}

Regarding the results obtained, the foreign money supply coefficient has the negative sign that is the opposite of the expectations. Also it is insignificant. Therefore, it can be concluded that this variable has no impact on trade balance.

Finally, the coefficient of the dummy variable of the Iran-Iraq war, has negative sign (-0.2034) and is significant at \% that implies the restrictive effects of the economic sanctions and the trade limits.

After investigating the long-run relationship of the variables, the error correction representation for the selected ARDL model has been obtained. The short-run coefficients obtained from the ECM version of the ARDL model has been reported in Table 4. According to Table 4, all of the variables have the expected sign and also they are statistically significant. Hence, there is an evidence of the short-run relationship among the variables. But as the long-run model, foreign money supply isn't significant. The error correction term in the short-run ECM model represents the speed of the adjustment which restores equilibrium in the dynamic model. Regarding to ECM estimation results, the coefficient of ECM (-1) is equal to (-0.6013) for short run model indicating any deviation from the long-term inequality is corrected by $60 \%$ over the each year.

\section{DISCUSSION}

The results show that the domestic real income has the greatest impact on the agricultural trade balance relative to other variables both in the short-and long-run On the other hand, real exchange rate has the positive effect on trade balance indicating that the depreciation will improve trade balance both in the short-and longrun period. Hence there's no evidence of $j$-curve in Iran's agricultural sector. This findings of the research is coordinate with the results of other researches. Yazici ${ }^{[13]}$ investigated the J-curve hypothesis in Turkish agricultural sector and his finding showed that $\mathrm{j}$-curve did not exist in this sector. Also Rose and Yelen ${ }^{[11]}$ did not find $\mathrm{j}$-curve effect in US On the other hand According to our finding, Foreign money supply had no relationship with trade balance; While the research by Baek and $\mathrm{Koo}^{[2]}$ showed the significant effect of this variable on U.S. agricultural trade balance

Domestic money supply has the lowest impact among variables on trade balance in the long-run and its effect is negative. ECM estimation results indicate that any deviation from the long-term inequality is corrected by $60 \%$ over the each year. The value of this coefficient implies the fairly high speed of adjustment to equilibrium.

\section{CONCLUSION}

According to the findings of this research, some policy implications can be suggested as follows:

- One of the main factors that worsen the trade balance, both in short-and long-run period is real domestic income. So, the policies that tend to increase domestic income, should be planned in such a way that the increased purchasing power of people will be directed to domestic goods rather than foreign goods. And it can be done by increasing the productivity in agricultural sector, improving the quality of production and better marketing system

- Another important finding is that the devaluation will intensify the trade balance. But it should be noted that the exchange rate isn't a robust instrument in Iran economy duo to internal and external socks, trade restrictions, taxes, subsidies and other of that kind. So it must be used in accompaniment with other policies such as supplyside policies such as rising labor productivity and wages or relaxing rigid labor market conditions

\section{REFERENCES}

1. Ardakani, Z., S. Yazdani and O. Gilanpour, 2009. Studying the Effects of Non-tariff Barriers on the Export of the Main Agricultural Products of Iran. Am. J. Applied Sci., 6: 1321-1326. http://www.scipub.org/fulltext/ajas/ajas6713211326.pdf

2. Fosu, A.K. and F. Magnus, 2006. Bounds testing approach to cointegration: An examination of foreign direct investment trade and growth relationships. Am. J. Applied Sci., 3: 2079-2081. http://www.scipub.org/fulltext/ajas/ajas31120792085.pdf 
3. Bahmani-Oskooee, M., 1985. Devaluation and the J- curve: Some evidence from LDCs. Rev. Econ. Stat., 67: 500-504. http://ideas.repec.org/a/tpr/restat/v67y1985i3p500504.html

4. Bahmani-Oskoee, M. and T. Kantiapong, 2001. Bilateral J-curve between Thailand and her Trading Partners. J. Econ. Develop., 26: 107-115. http://www.econ.cau.ac.kr/jed/newjed/full-text/262/oskooee.PDF

5. Engle, R.F. and .W.J. Granger, 1987. Cointegration and error correction representation: Estimation and testing. Econometrica, 55: 251-276. http://ideas.repec.org/a/ecm/emetrp/v55y1987i2p2 51-76.html

6. Carter, C. and D. Pick, 1989. The J-curve effect and the us agricultural trade policy. Am. J. Agric. Econ., 71:

712-720. http://www.jstor.org/stable/1242027

7. Mehrara M. and A. Abdi, 2007. The factors affecting trade balance in Iran economy. Q. J. Econ. Res. Iran Econ., 31: 2-3. http://www.sid.ir/fa/VEWSSID/J_pdf/5071386310 1.pdf

8. Narayan, P.K., 2004. New Zealand's Trade Balance: Evidence from the J-curve and Granger causality. Applied Econ. Lett., 11: 351-354. DOI: 10.1080/1350485042000228187
9. Pesaran, M.H. and Y. Shin, 1999. An autoregressive distributed lag modeling approach to cointegration analysis. Proceeding of the Symposiumon Econometrics and Economic Theory in the 20th Century: The Ragnar Frisch Centennial. Cambridge University Press, Cambridge, pp: 371-413.

10. Pesaran, M., Y. Shin and R.J. Smith, 2001. Bounds testing approaches to the analysis of level relationships. J. Applied Econ., 16: 289-326. DOI: 10.1002/jae.616

11. Rose, A.K. and J.L. Yellen, 1989. Is There a JCurve? J. Monetary Econ., 24: 53-68. DOI: 10.1016/0304-3932(89)90016-0

12. Stučka, T., 2004. The effects of exchange rate change on the trade balance in Croatia. MF Working Paper, P/04/65,10-14. http://ideas.repec.org/p/imf/imfwpa/04-65.html

13. Yazici, M., 2006. Is the J-curve effect observable in Turkish agricultural sector? J. Central Eur. Agric., 7: 320-321.

http://www.agr.hr/jcea/issues/jcea7-2/pdf/jcea7211.pdf 